\title{
Short communication: Antiviral activity of subcritical water extract of Brassica juncea against influenza virus $\mathrm{A} / \mathrm{H} 1 \mathrm{~N} 1$ in nonfat milk
}

\author{
N.-K. Lee, ${ }^{*}$ J.-H. Lee, ${ }^{*}$ S.-M. Lim, ${ }^{*}$ K. A. Lee, ${ }^{*}$ Y. B. Kim,† P.-S. Chang, $\ddagger$ and H.-D. Paik${ }^{*}{ }^{1}$ \\ *Department of Food Science and Biotechnology of Animal Resources, Konkuk University, Seoul 143-701, Republic of Korea \\ †Department of Biotechnology, Konkuk University, Seoul 143-701, Republic of Korea \\ fDepartment of Agricultural Biotechnology, Seoul National University, Seoul 151-742, Republic of Korea \\ $\S B i o / M o l e c u l a r$ Informatics Center, Konkuk University, Seoul 143-701, Republic of Korea
}

\section{ABSTRACT}

Subcritical water extract (SWE) of Brassica juncea was studied for antiviral effects against influenza virus $\mathrm{A} / \mathrm{H} 1 \mathrm{~N} 1$ and for the possibility of application as a nonfat milk supplement for use as an "antiviral food." At maximum nontoxic concentrations, SWE had higher antiviral activity against influenza virus A/H1N1 than $n$-hexane, ethanol, or hot water $\left(80^{\circ} \mathrm{C}\right)$ extracts. Addition of $0.5 \mathrm{mg} / \mathrm{mL}$ of $B$. juncea SWE to culture medium led to $50.35 \%$ cell viability (\% antiviral activity) for Madin-Darby canine kidney cells infected with influenza virus A/H1N1. Nonfat milk supplemented with $0.28 \mathrm{mg} / \mathrm{mL}$ of B. juncea SWE showed $39.62 \%$ antiviral activity against influenza virus $\mathrm{A} / \mathrm{H} 1 \mathrm{~N} 1$. Thus, the use of $B$. juncea SWE as a food supplement might aid in protection from influenza viral infection.

Key words: Brassica juncea, influenza virus, antiviral activity, subcritical water extraction

\section{Short Communication}

Medicinal plants have been studied for various properties, including antioxidant, antibacterial, and antiviral activities (Park, 2003; Shan et al., 2007; Veskoukis et al., 2012). Most of the antiviral effects possessed by medicinal plants are related to the presence of a variety of phytochemicals, such as alkaloids, flavonoids, glucosides, polyphenols, and saponins (Mukhtar et al., 2008). Several different antiviral mechanisms have been described for plant extracts, including immune modulation, prevention of host cell penetration, as well as inhibition of neuraminidase, uncoating, and nucleic acid synthesis (Strasfeld and Chou, 2010). Brassica juncea, commonly called brown mustard, has traditionally been used as an herbal drug with anticarcinogenic and antimicrobial properties (Rhee et al., 2003; Lee

Received February 4, 2014.

Accepted April 29, 2014.

${ }^{1}$ Corresponding author: hdpaik@konkuk.ac.kr et al., 2010). Brassica juncea extract is composed of glucosinolates (sinigrin, gluconapin, and glucobrassicin), phenolic compounds, flavonoids, phytic acid, and brassinosteroids (Fabre et al., 1996; Munday and Munday, 2004). Among these components, brassinosteroids are naturally occurring polyhydroxy steroids and are reported to have antiviral activity against pathogenic viruses (Kumar and Andy, 2012).

Influenza A viruses are negative-strand RNA viruses that belong to the family Orthomyxoviridae; they have a segmented genome and possess 2 external glycosylated proteins - hemagglutinin (HA) and neuraminidase (NA; Hennet et al., 1992; Beigel and Bray, 2008). The influenza virus has been shown to be a major viral respiratory tract pathogen with worldwide prevalence. In the United States, zanamivir (Relenza, Glaxo Smith Kline, Research Triangle Park, NC) and oseltamivir (Tamiflu, Gilead Sciences, Foster City, CA) are US Food and Drug Administration-approved antiviral drugs for influenza (Vergara-Jaque et al., 2012). However, resistance to these therapies was recently reported during the 2009 pandemic of influenza virus (A/H1N1). Therefore, it is necessary to develop novel antiviral agents without any side effects.

Subcritical water extraction is based on the unique solvent properties of water. The advantages of this method compared with traditional extraction methods include shorter time for extraction, higher quality of the extract, and an environmentally compatible technique (Herrero et al., 2006). The potential antiviral activity of methanol extracts of $B$. juncea against influenza virus $\mathrm{A} / \mathrm{H} 1 \mathrm{~N} 1$ has been shown previously (Lee et al., 2010). However, B. juncea SWE has not been studied for this activity. Therefore, we investigated the antiviral effects of $B$. juncea SWE against influenza virus and as a supplement to nonfat milk.

Madin-Darby canine kidney (MDCK) cells were obtained from the Korean Cell Line Bank (KCLB, Seoul, Korea). The MDCK cells were cultivated with Eagle's minimum essential medium (EMEM; Invitrogen, Carlsbad, CA) containing $10 \%$ heat-inactivated fetal 
Table 1. Cytotoxicity and antiviral activity of various extracts of Brassica juncea against influenza virus A/ H1N1

\begin{tabular}{lccc}
\hline Solvent & $\begin{array}{c}\text { Yield } \\
(\mathrm{g} / \mathrm{g})\end{array}$ & $\begin{array}{c}\text { MNTC } \\
(\mathrm{mg} / \mathrm{mL})\end{array}$ & $\begin{array}{c}\text { Antiviral activity } \\
\text { at }\end{array}$ \\
\hline Subcritical water $\left(110^{\circ} \mathrm{C}\right)$ & 0.14 & 0.5 & 50.35 \\
$n$-Hexane & 0.25 & 0.041 & $\mathrm{NI}^{2}$ \\
Ethanol & 0.13 & 1.5 & 40 \\
Hot water $\left(80^{\circ} \mathrm{C}\right)$ & 0.16 & $>25$ & $\mathrm{NI}$ \\
${ }^{1} \mathrm{MNTC}=$ maximum nontoxic concentration. & & \\
${ }^{2} \mathrm{NI}=$ no inhibition. & &
\end{tabular}

bovine serum, $100 \mathrm{U} / \mathrm{mL}$ penicillin, and $0.1 \mathrm{mg} / \mathrm{mL}$ streptomycin. The A/Puerto Rico/8/34 strain of influenza virus type A was propagated in 10-d-old embryonated eggs in an approved biosafety level-2 facility. The viral growth medium for generating virus pools and performing antiviral assays consisted of EMEM with $10 \%$ BSA (Invitrogen, Paisley, UK), antibiotics, and $\mathrm{N}$-tosyl-L-phenylalanine chloromethyl ketone-treated trypsin per milliliter.

To perform extraction from $B$. juncea seeds, a subcritical extractor system (Dionex ASE 100; Dionex Corp., Sunnyvale, CA) was utilized. The extractions were performed using only distilled water as a solvent. Powdered B. juncea seeds and diatomaceous earth (DE) were mixed in stainless steel cells at a sample to DE ratio of 1:3. The cell volume was $34 \mathrm{~mL}$ and the cells were equipped with filters. The extraction temperature and static time were set to $110^{\circ} \mathrm{C}$ and $10 \mathrm{~min}$, respectively. The collected extracts were stored at $4^{\circ} \mathrm{C}$ until further study.

Extractions using $n$-hexane, ethanol, and hot water were performed. For each of the $n$-hexane and ethanol extracts, $100 \mathrm{~g}$ of $B$. juncea seeds was extracted for $24 \mathrm{~h}$ at room temperature using $1 \mathrm{~L}$ of each solvent. For hot water extraction, $100 \mathrm{~g}$ of $B$. juncea seeds was extracted with $1 \mathrm{~L}$ of water for $3 \mathrm{~h}$ in an $80^{\circ} \mathrm{C}$ water bath. After filtration through Whatman No. 1 filter paper, the filtrate was concentrated by using a rotary evaporator. The concentrates were lyophilized and then stored at $4^{\circ} \mathrm{C}$ until used.

Brassica juncea SWE was added to nonfat sterilized milk at a concentration of $2.5 \mathrm{mg} / \mathrm{mL}$ and stored at $4^{\circ} \mathrm{C}$ for $8 \mathrm{~d}$. After the storage period, the SWE was serially diluted 3-fold and mixed with the medium for use in antiviral evaluation.

The maximum nontoxic concentration of the SWE sample was determined based on the measurement of cell viability. First, MDCK cells $\left(1.5 \times 10^{4}\right.$ cells/well $)$ were seeded in 96 -well plates and incubated in $5 \% \mathrm{CO}_{2}$ at $37^{\circ} \mathrm{C}$ for $16 \mathrm{~h}$. When cell growth reached confluence, the medium was removed and replaced with $100 \mu \mathrm{L}$ of the medium containing the serially diluted sample.
After incubation for $48 \mathrm{~h}$, the medium was aspirated and $50 \mu \mathrm{L}$ of 3-(4,5-dimethylthiazol-2-yl)-2,5-diphenyl tetrazolium bromide (MTT; Sigma-Aldrich, St. Louis, MO) solution was added to each well and the plates were incubated for $4 \mathrm{~h}$. The MTT solution was removed without disturbing the cells, and $100 \mu \mathrm{L}$ of dimethyl sulfoxide was added to each well to dissolve the formazan crystals. After gently shaking the plates to dissolve the crystals completely, the absorbance was read using a microplate reader (Molecular Devices, Seoul, Korea) at $540 \mathrm{~nm}$. The percentage survival was calculated using the optical density of treated versus control samples.

The MDCK cells were seeded in 96-well plates at 1.5 $\times 10^{4}$ cells/well and incubated for $16 \mathrm{~h}$ in a $5 \% \mathrm{CO}_{2}$ incubator at $37^{\circ} \mathrm{C}$. When cell monolayers were confluent, the medium was removed from the wells and washed twice with $100 \mu \mathrm{L}$ of PBS, and then infected with influenza virus at $100 \times 50 \%$ tissue culture infectious dose $\left(\right.$ TCID $\left._{50}\right)$ for $2 \mathrm{~h}$ at $37^{\circ} \mathrm{C}$. After the unabsorbed viruses were removed, the cell sheet was incubated with the virus growth medium containing serially diluted samples at $37^{\circ} \mathrm{C}$. After $48 \mathrm{~h}$, all wells were observed and scored for viral cytopathic effects under the light microscope, and the MTT assay was conducted as described above. For each sheet, controls infected with 100 TCID $_{50}$ of virus and mock controls uninfected and untreated were included in all experiments. The percentage protection were calculated by using the formula $[(\mathrm{A}-\mathrm{B}) /(\mathrm{C}-$ $\mathrm{B})] \times 100$, where $\mathrm{A}, \mathrm{B}$, and $\mathrm{C}$ indicate the absorbance values of the sample, virus, and cell controls, respectively. Each experiment was conducted as 3 replicates.

Herbal remedies are generally perceived as harmless. However, several studies have suggested that cytotoxicity may be associated with herbal medications (Pak et al., 2004). Therefore, the cytotoxicity of B. juncea extracts was assessed using MDCK cells. Supercritical water extract and ethanol extract of $B$. juncea were found to be nontoxic to MDCK cells at 0.5 and $1.5 \mathrm{mg} /$ $\mathrm{mL}$, respectively. The antiviral activity was then evaluated by MTT assay in MDCK cells inoculated with influenza virus. At maximum nontoxic concentrations, SWE and ethanol extract were shown to have $50.35 \%$ 


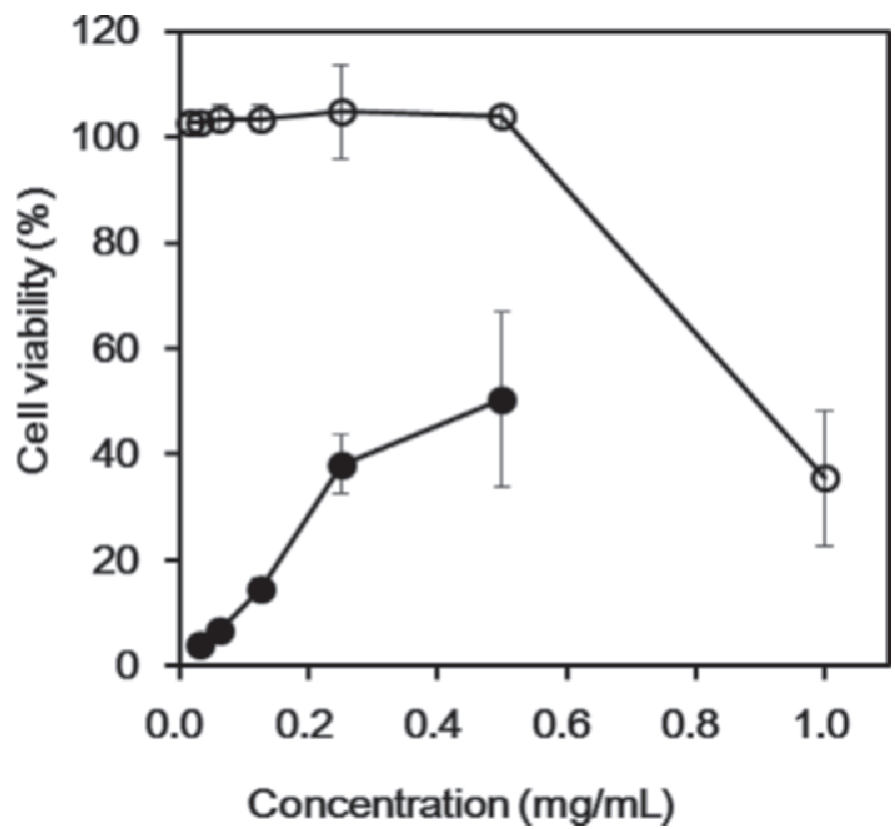

Figure 1. Cell viability $(\bigcirc)$ and antiviral activity against influenza virus A/H1N1 (-) of Brassica juncea subcritical water extract (SWE) on Madin-Darby canine kidney cells.

and $40 \%$ antiviral activity against influenza virus A/ H1N1, respectively (Table 1), indicating that SWE was a more efficient and environmentally friendly method than the traditional extraction method.

The antiviral activity of $B$. juncea SWE was evaluated according to the concentration for infected MDCK cells (Figure 1). The antiviral activity of B. juncea SWE was 50.35 and $38.11 \%$ at 0.5 and $0.25 \mathrm{mg} / \mathrm{mL}$, respectively, showing that the activity of the extract is concentration dependent. Growth of MDCK cells was not inhibited at $0.5 \mathrm{mg} / \mathrm{mL}$ of B. juncea SWE, whereas MDCK cell damage was induced at $1 \mathrm{mg} / \mathrm{mL}$ of $B$. juncea SWE. Thus, we observed no relationship between cell viability and antiviral activity. These results are consistent with those of previous studies showing that the minimum cytopathic effects (CPE) inhibitory concentration of methanol extracts of $B$. juncea against influenza virus A/H1N1 was $0.3 \mathrm{mg} / \mathrm{mL}$ (Lee et al., 2010).

Influenza virus $\mathrm{A} / \mathrm{H} 1 \mathrm{~N} 1$ was inactivated by nonfat milk supplemented with $2.5 \mathrm{mg} / \mathrm{mL}$ of $B$. juncea $\mathrm{SWE}$ (Figure 2). Viral inactivation was dependent on the concentration of the extract. At $0.28 \mathrm{mg} / \mathrm{mL}$ of $B$. juncea SWE, 39.62\% antiviral activity was detected. Similar antiviral activity was observed when $B$. juncea SWE was dissolved in EMEM (Figure 1).

Oral administration of lactoferrin and lactoperoxidase in bovine milk has the potential to protect against infectious diseases such as influenza (Shin et al., 2005). In addition, consumption of whey protein of bovine

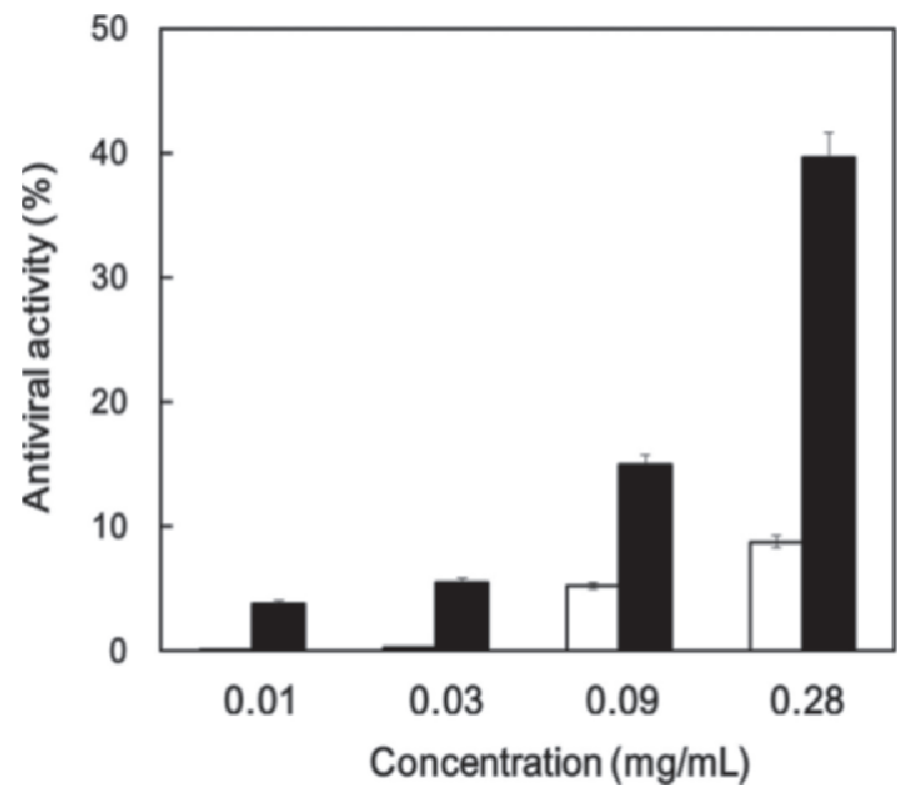

Figure 2. Antiviral activity of nonfat milk ( $\square$ ) and nonfat milk supplemented with Brassica juncea subcritical water extract (SWE; $\mathbf{\square})$ against influenza virus A/H1N1 on Madin-Darby canine kidney cells.

milk has been shown to enhance the humoral immune response (Low et al., 2003). Although milk peptides have been reported to inhibit intestinal absorption of the neuraminidase inhibitor oseltamivir (Morimoto et al., 2011), the current study showed synergistic effects between milk and $B$. juncea SWE.

The antiviral activity of $B$. juncea was evaluated as SWE and $n$-hexane, ethanol, and hot water extracts. In these extracts, SWE had the highest antiviral activity against influenza virus A/H1N1. Furthermore, the antiviral activity of $B$. juncea SWE was maintained in nonfat milk without loss. Therefore, B. juncea SWE may be used as a food supplement in dairy products to prevent infection caused by influenza virus.

\section{ACKNOWLEDGMENTS}

This study was supported by a grant (\#20070401034025) from Biogreen 21 program, Rural Development Administration, Korea, and also supported by Priority Research Centers Program through the National Research Foundation of Korea (NRF) funded by the Ministry of Education, Science and Technology (2012-0006686), Korea.

\section{REFERENCES}

Beigel, J., and M. Bray. 2008. Current and future antiviral therapy of severe seasonal and avian influenza. Antiviral Res. 78:91-102.

Fabre, N., M. Bon, C. Moulis, I. Fouraste, and E. Stanislas. 1996. Three glucosinolates from seeds of Brassica juncea. Phytochemistry $45: 525-527$. 
Hennet, T., E. Peterhans, and R. Stocker. 1992. Alterations in antioxidant defences in lung and liver of mice infected with influenza A virus. J. Gen. Virol. 73:39-46.

Herrero, M., A. Cifuentes, and E. Ibanez. 2006. Sub- and supercritical fluid extraction of functional ingredients from different natural sources: Plants, food-by-products, algae and microalgae: A review. Food Chem. 98:136-148.

Kumar, S., and A. Andy. 2012. Health promoting bioactive phytochemicals from Brassica. Int. Food Res. J. 19:141-152.

Lee, J. H., N. D. Van, J. Y. Ma, Y. B. Kim, S. K. Kim, and H. D. Paik. 2010. Screening of antiviral medicinal plants against avian influenza virus H1N1 for food safety. Korean J. Food Sci. Anim. Resour. 30:345-350.

Low, P. P., K. J. Rutherfurd, H. S. Gill, and M. L. Cross. 2003. Effect of dietary whey protein concentrate on primary and secondary antibody responses in immunized BALB/c mice. Int. Immunopharmacol. 3:393-401.

Morimoto, K., K. Kishimura, T. Nagami, N. Kodama, Y. Ogama, M. Yokoyama, S. Toda, T. Chiyoda, R. Shimada, S. Inano, T. Kano, I. Tamai, and T. Ogihara. 2011. Effect of milk on the pharmacokinetics of oseltamivir in healthy volunteers. J. Pharm. Sci. 100:3854-3861.

Mukhtar, M., M. Arshad, M. Ahmed, R. J. Pomerantz, B. Wigdahl, and Z. Parveen. 2008. Antiviral potentials of medicinal plants. Virus Res. 131:111-120.

Munday, R., and C. M. Munday. 2004. Induction of phase II detoxification enzymes in rats by plant-derived isothiocyanates: Comparison of allyl isothiocyanate with sulforaphane and related compounds. J. Agric. Food Chem. 52:1867-1871.
Pak, E., K. T. Esrason, and V. H. Wu. 2004. Hepatotoxicity of herbal remedies: An emerging dilemma. Prog. Transplant. 14:91-96.

Park, K. J. 2003. Evaluation of in vitro antiviral activity in methanol extracts against influenza virus type A from Korean medicinal plants. Phytother. Res. 17:1059-1063.

Rhee, M. S., S. Y. Lee, R. H. Dougherty, and D. H. Kang. 2003 Antimicrobial effects of mustard flour and acetic acid against Escherichia coli O157:H7, Listeria monocytogenes, and Salmonella enterica serovar Typhimurium. Appl. Environ. Microbiol. 69:2959-2963.

Shan, B., Y. Z. Cai, J. D. Brooks, and H. Corke. 2007. The in vitro antibacterial activity of dietary spice and medicinal herb extracts. Int. J. Food Microbiol. 117:112-119.

Shin, K., H. Wakabayashi, K. Yamauchi, S. Teraguchi, Y. Tamura, M. Kurokawa, and K. Shiraki. 2005. Effects of orally administered bovine lactoferrin and lactoperoxidase on influenza virus infection in mice. J. Med. Microbiol. 54:717-723.

Strasfeld, L., and S. Chou. 2010. Antiviral drug resistance: Mechanisms and clinical implications. Infect. Dis. Clin. North Am. 24:413-437.

Vergara-Jaque, A., H. Poblete, E. H. Lee, K. Schulten, F. GonzalezNilo, and C. Chipot. 2012. Molecular basis of drug resistance in A/ H1N1 virus. J. Chem. Inf. Model. 52:2650-2656.

Veskoukis, A. S., A. M. Tsatasakis, and D. Kouretas. 2012. Dietary oxidative stress and antioxidant defense with an emphasis on plant extract. Cell Stress Chaperones 17:11-21. 